\title{
MONITORING OF ACTIVE TECTONIC STRUCTURES - PROJECT COST 625
}

\author{
SPREMLJANJE AKTIVNIH TEKTONSKIH STRUKTUR - \\ PROJEKT COST 625 \\ STANKA ŠEBELA ${ }^{1}$
}

${ }^{1}$ IZRK ZRC SAZU, Titov trg 2, 6230 Postojna, Slovenia, sebela@zrc-sazu.si

Prejeto / Received: 2. 11. 2005 


\section{Abstract \\ Stanka Šebela: Monitoring of active tectonic structures - Project COST 625}

UDC: 551.24 .001 .5

For Western Slovenia moderate historical to recent seismicity is characteristic. The principal aim for Slovenia to join the COST 625 project was to exchange the experiences and methodology and in this way to determine the activity or non-activity of selected faults in Western Slovenia. Within the project frame we decided for several years of monitoring, and in this sense four TM 71 extensometers were installed in Western Slovenia. In the first half of the 2004 two TM 71 instruments were installed in Postojnska Jama on the Dinaric oriented fault that is situated about $1 \mathrm{~km}$ North from Predjama fault. The third instrument was installed on Raša fault on the SE slope of Vremščica and the fourth instrument in Učja valley on Idrija fault. The fifth instrument TM 71 will be set up on Kneža fault that is situated south from Ravne fault. The first results from Postojnska Jama are showing the small horizontal movements for $0.05 \mathrm{~mm}$ in one year.

Key words: active tectonic structures, monitoring, project COST 625.

\section{Izvleček}

UDK: 551.24.001.5

\section{Stanka Šebela: Spremljanje aktivnih tektonskih struktur - projekt COST 625}

Za zahodno Slovenijo je značilna zmerna zgodovinska in recentna seizmičnost. Glavni cilj pridružitve Slovenije k projektu COST 625 je bil, da bi z izmenjavo izkušenj in metodologije ugotovili aktivnost ali neaktivnost določenih prelomov v zahodni Sloveniji. V okviru projekta smo se odločili za večletni monitoring, zato smo v zahodni Sloveniji namestili štiri ekstenziometre TM 71. V prvi polovici letu 2004 smo v Postojnski jami na dinarski prelom, ki je od Predjamskega preloma oddaljen okrog 1 km severno, postavili dva inštrumenta. Tretji inštrument je postavljen na Raškem prelomu na JV pobočju Vremščice in četrti v dolini Učje na Idrijski prelom. Peti inštrument TM 71 bo postavljen na Kneškem prelomu, ki se nahaja južno od Ravenskega preloma. Prvi rezultati v Postojnski jami kažejo na manjše horizontalne premike velikosti do $0,05 \mathrm{~mm}$ v enem letu.

Ključne besede: aktivne tektonske strukture, monitoring, projekt COST 625. 


\section{INTRODUCTION}

For Western Slovenia moderate historical to recent seismicity is characteristic. The earthquakes in Soča valley in the last years (April 12, $1998 \mathrm{M}=5.6$ and July 12, $2004 \mathrm{M}=4.9$, Zupančič et al., 2001) are showing the existence of the active fault zones especially Ravne and Kneža faults. For other morphologically well-expressed faults it is almost impossible to threat them as active faults due to the lack of seismic activity. The principal aim for Slovenia to join the COST 625 project was to exchange the experiences and methodology and in this way to determine the activity or non-activity of selected faults in Western Slovenia.

The principal research methods that are used within the project are:

- Geological and geomorphologic field mapping with detection of surface ruptures and other morphological signs (offset river valleys and river terraces etc.)

- Seismic analyses

- GPS, LiDAR and geodetic measurements

- Measurements of the movements with TM 71 extensometers.

In Slovenia we decided to use the TM 71 extensometer, which was developed by dr. Blahoslav Košták (Košták, 1969). Tectonic deformation, the subject of the COST 625 project, occurs on a very long time scale, in order of less than one millimeter per year. The characteristic of TM 71 is long-term measurement of the movements with accuracy of up to $0.01 \mathrm{~mm}$ (Šebela et al. 2005).

Slovenia joined the COST 625 project ("3-D monitoring of active tectonic structures") on March 16, 2000. Today the project unites 21 countries. First the project was part of the Environment and from August 2004 it is under the field of Cultural Heritage. The official beginning of the project is February 9, 2000 and the end of the project February 8, 2006. The project runs in two working groups (WGAT - Working Group for Active Tectonics; WGMI - Working Group for Monitoring and Instrumentation).

The principal objective of the project is the research of micro displacements on active tectonic structures, which can be seismic or aseismic. The results about micro displacements on the seismically active areas could be correlated by seismic events. In seismically less active areas the results of micro displacements are representing the data about slow tectonic processes.

TM 71 is a mechanical and optical instrument that measures the displacements in three dimensions $(x, y$ and $z)$. The measurement works on the principle of Moiré optical effect, which changes when two transparent plates move (Košt’ák, 1977, 1991). Each plate is fixed into the outcrop of fault plane or fissure. The instrument can be installed into the fissure up to $1,5 \mathrm{~m}$ wide. Because most of the fault zones are much wider, the installation is generally placed between one of the fault planes and tectonically deformed rock or fissure on the other side. The TM 71 instrument is very resistant and simple and doesn't need any source of the energy. This is good for longtime observations under different climate conditions (Avramova-Tacheva \& Košt'ák, 1995). We need to perform the measurements at least three years once or three times a month to eliminate other possible causes for the movements.

The processes that are registered by TM 71 are representing the tensions in Earth's crust. We need to be familiar with deformational models of rheology in the connection with structural changes. The most interesting are the movements along seismically active faults. We also need to distinguish between movements registered due to the tectonic deformations of the Earth's crust and other surface movements, especially gravitational. It is recommended to use other methods as GPS to reduce the interpretation errors.

The movements registered by TM 71 usually consist of two elements: 
- Occasional differences of different amplitudes connected with deformations in rocks or due to the temperature changes, humidity etc.

- Permanent movements or sudden jumps (Košták \& Avramova-Tacheva, 1984; Kalvoda \& Košt'ák, 1984; Avramova-Tacheva \& Košt’ák, 1986).

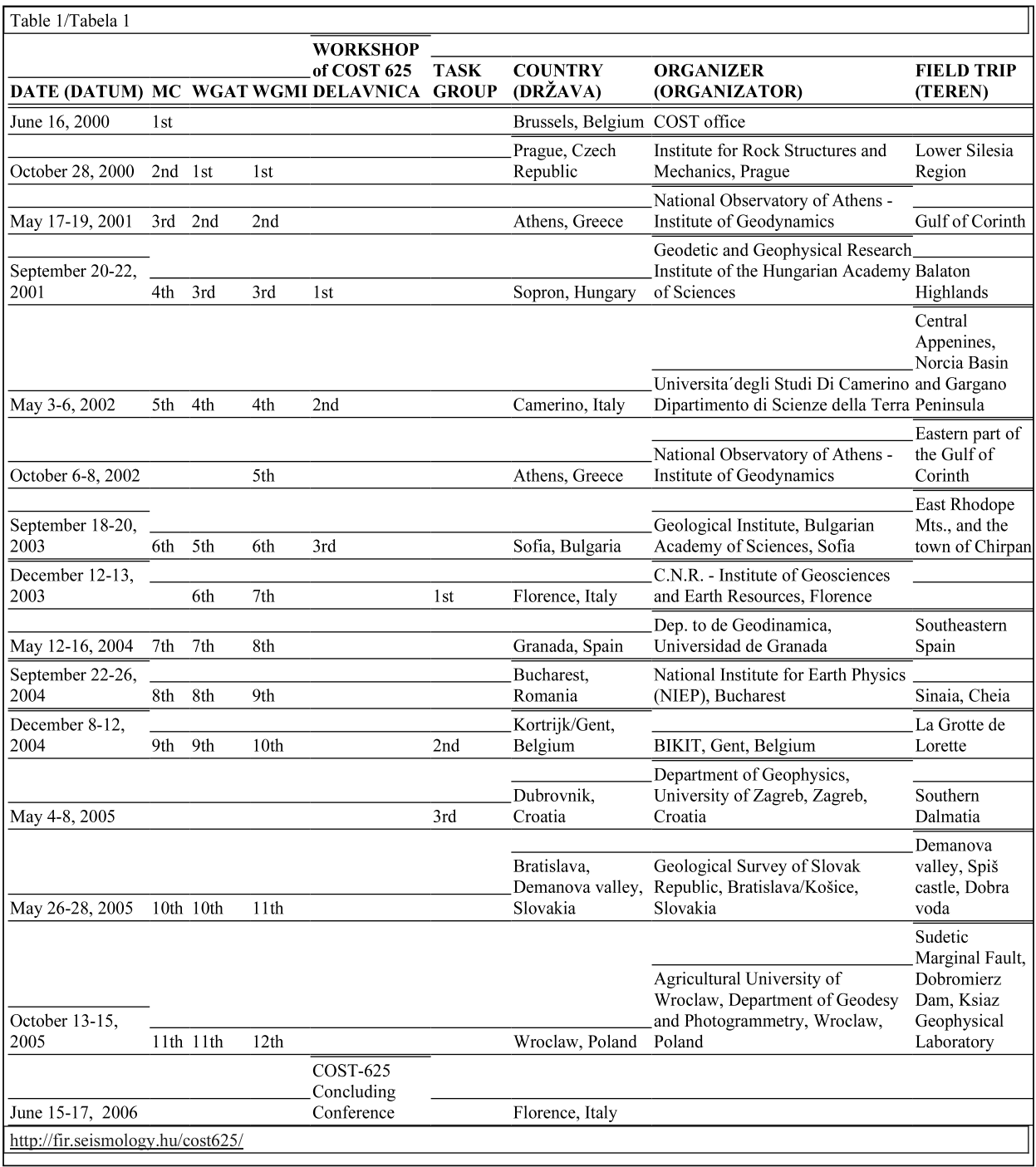

Table 1: Meetings of the COST 625 project group. MC - Members Committee, WGAT - Working Group for Active Tectonics, WGMI - Working Group for Monitoring and Instrumentation, Task Group - "Map of Active Faults".

Tabela 1. Srečanja projektne skupine COST 625. MC - članski odbor, WGAT-Delovna skupina za aktivno tektoniko, WGMI - Delovna skupina za monitoring in opremo, Task Group - "Karta aktivnih prelomov". 
The analysis of movements detected with TM 71 indicated that stronger earthquakes are not accompanied by sudden jumps but with slow growing of the movement before the earthquake (Shanov, 1993) and slow decreasing of the movement after the earthquake.

\section{MEETINGS OF THE COST 625 PROJECT GROUP AND SLOVENE PARTICIPATION}

The COST 625 project participant countries accomplished 11 Members Committee meetings in six years. The project is one of the most active COST projects. The activity of the group was always encouraged by first president dr. Blahoslav Košták and the present president dr. Luigi Piccardi. In Table 1 the meetings of the COST 625 project group (http://fir.seismology.hu/cost625/) and the field works are presented.

Besides regular COST 625 meetings the "Training School, European Advanced School on Tectonics" (Trieste, Italy, April 18-22, 2005) for students was organized by dr. Luigi Piccardi. The financial support was organized by ESF - European Sciences Foundation and COST 625. Three Slovene ph D students (Vanja Kastelic, Jure Žalohar and Mitja Prelovšek) frequented the international school in Trieste. On April 19, 2005 Stanka Šebela performed two presentations (Active structural geological elements and karst features; Karst caves and structural geology, examples from China, USA and Slovenia).

Even though if Slovenia was included in the COST 625 already in 2000, we started to participate in the Members Committee meeting in May 2002 in Camerino Italy, due to the previous administrative errors. The Karst Research Institute ZRC SAZU is part of the project from the beginning, and University in Ljubljana, Department of Geology from September 24, 2002.

In the Table 2 Slovene participants of the COST 625 meetings are collected.

\begin{tabular}{|c|c|c|c|c|c|c|c|}
\hline \multicolumn{8}{|c|}{ Table 2/Tabela 2} \\
\hline $\begin{array}{c}\text { DATE } \\
\text { (DATUM) }\end{array}$ & MC & WGAT & WGMI of & $\begin{array}{l}\text { WORKSHOP } \\
\text { f COST } 625\end{array}$ & $\begin{array}{l}\text { TASK } \\
\text { GROUP }\end{array}$ & $\begin{array}{l}\text { COUNTRY } \\
\text { (DRŽAVA) }\end{array}$ & SLOVENE PARTICIPANTS \\
\hline $\begin{array}{l}\text { May 3-6, } \\
2002\end{array}$ & 5 th & 4th & 4th & 2nd & & Camerino, Italy & Stanka Šebela \\
\hline $\begin{array}{c}\text { September } \\
18-20,2003\end{array}$ & 6th & 5 th & 6th & 3rd & & Sofia, Bulgaria & Stanka Šebela, Andrej Gosar \\
\hline $\begin{array}{l}\text { May 12-16, } \\
2004\end{array}$ & 7th & 7th & 8th & & & Granada, Spain & Andrej Gosar \\
\hline $\begin{array}{l}\text { September } \\
22-26,2004\end{array}$ & 8th & 8 th & 9th & & & $\begin{array}{l}\text { Bucharest, } \\
\text { Romania }\end{array}$ & Stanka Šebela, Janez Mulec \\
\hline $\begin{array}{l}\text { May 4-8, } \\
2005\end{array}$ & & & & & $3 \mathrm{rd}$ & $\begin{array}{l}\text { Dubrovnik, } \\
\text { Croatia }\end{array}$ & $\begin{array}{l}\text { Andrej Gosar, Marijan Poljak, } \\
\text { Bogomir Celarc }\end{array}$ \\
\hline $\begin{array}{l}\text { May 26-28, } \\
2005\end{array}$ & $10 \mathrm{~h}$ & 10th & 11th & & & $\begin{array}{l}\text { Bratislava, } \\
\text { Demanova valley, } \\
\text { Slovakia }\end{array}$ & Stanka Šebela, Janez Mulec \\
\hline $\begin{array}{l}\text { October 13- } \\
15,2005\end{array}$ & 11 th & 11th & 12th & & & $\begin{array}{l}\text { Wroclaw, } \\
\text { Poland }\end{array}$ & Janez Mulec \\
\hline
\end{tabular}

Table 2: Slovene participants at the meetings of the COST 625 project group. MC - Members Committee, WGAT - Working Group for Active Tectonics, WGMI - Working Group for Monitoring and Instrumentation, Task Group - "Map of Active Faults".

Tabela 2. Slovenski udeleženci srečanj projektne skupine COST 625. MC - članski odbor, WGAT - Delovna skupina za aktivno tektoniko, WGMI - Delovna skupina za monitoring in opremo, Task Group - "Karta aktivnih prelomov". 
The first meeting with Slovene participants was in Italy. In the area around Camerino we have seen the surface rupture $(1-2 \mathrm{~cm})$ on the fault plane (Figure 1), which is the result of the earthquakes between September 26 and October 14, 1997. The group visited Gargano peninsula where there are many active faults.

In Bulgaria we have seen one of the many active landslides (Figure 2) in the area of East Rhodope Mts., SE Bulgaria. On the field we discussed about the landslide influence on the General Geshevo village, which is situated about $6 \mathrm{~km} \mathrm{SE}$ from the town of Dzhebel. Ancient and recent landslides occur in the examined area. The mechanical model of the slope destruction could be represented as two-layered media consisting of an upper fragile layer and a lower plastic one. An Oligocene rhyoliteperlite dome lies on sandstones and clays. The preparatory stage of the landslide could last tens to even hundred of years. The active stage lasts from few days up to few months. The vertical move is from 1-4 m to 8-10 m, and horizontal move reaches up to 15-20 m. In the autumn-winter period of 2000-2001 the real sliding occurred. Tectonic uplift, incising/cutting of the river-gully network, and superficial water and ground water are the main destabilizing agents (Brouchev et al. 2001).

Dr. Shanov, who is geologist and speleologist, described the studies of tectonic trench that was done for understanding the very strong old Chirpan earthquake on April 18, 1928 (M=7.0).

Focal mechanism of the 18 April 1928 earthquake gives normal-dextral slip. There are manifestations of liquefaction, mud and sand volcanoes along the Sokolitsa River, scarps in topography

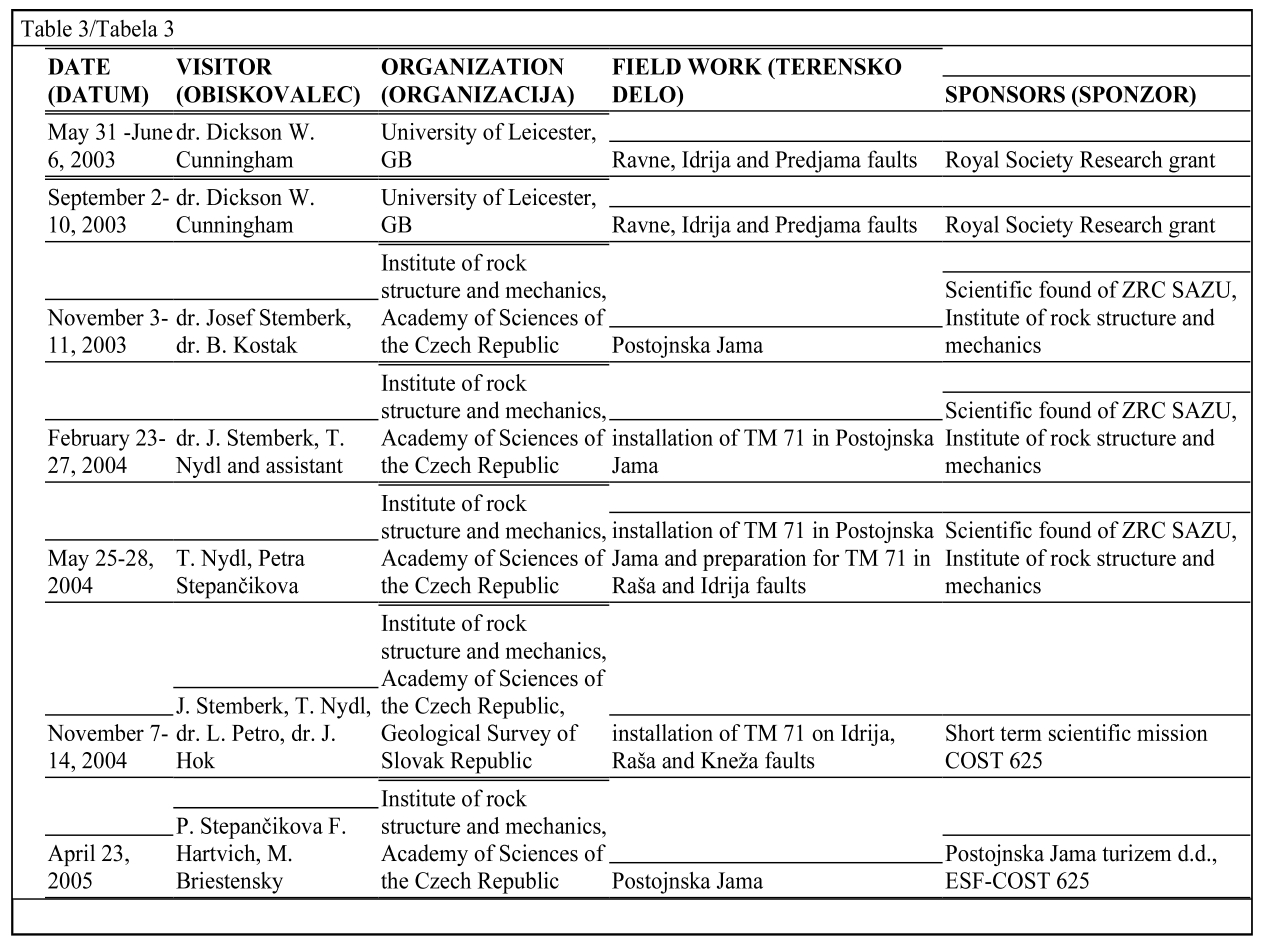

Table 3: Participants from other COST 625 countries in Slovenia.

Tabela 3: Obiski predstavnikov drugih držav članic COST 625 v Sloveniji. 


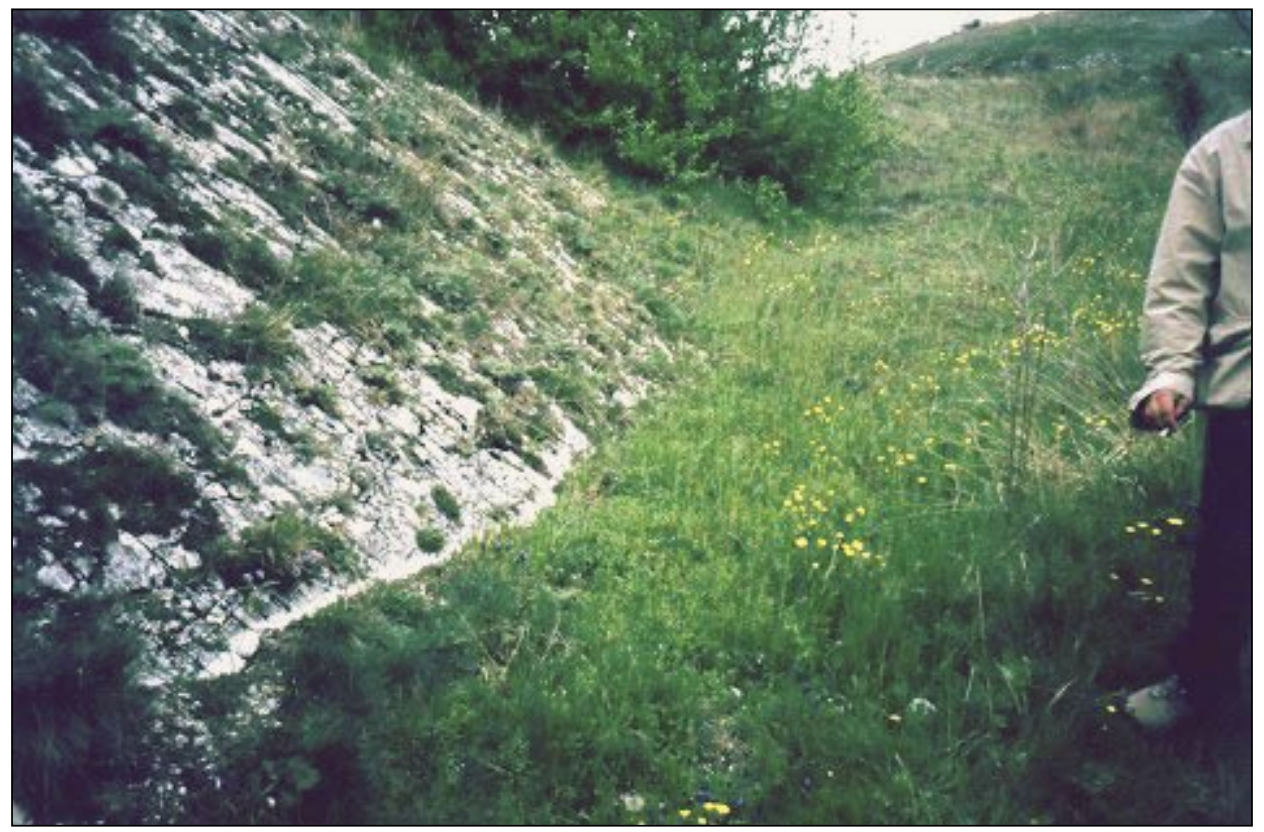

Figure 1: Surface rupture in Italy, Colfiorito (photo S. Šebela).

Slika 1: Površinski pretrg v osrednji Italiji, Colfiorito (foto S. Šebela).

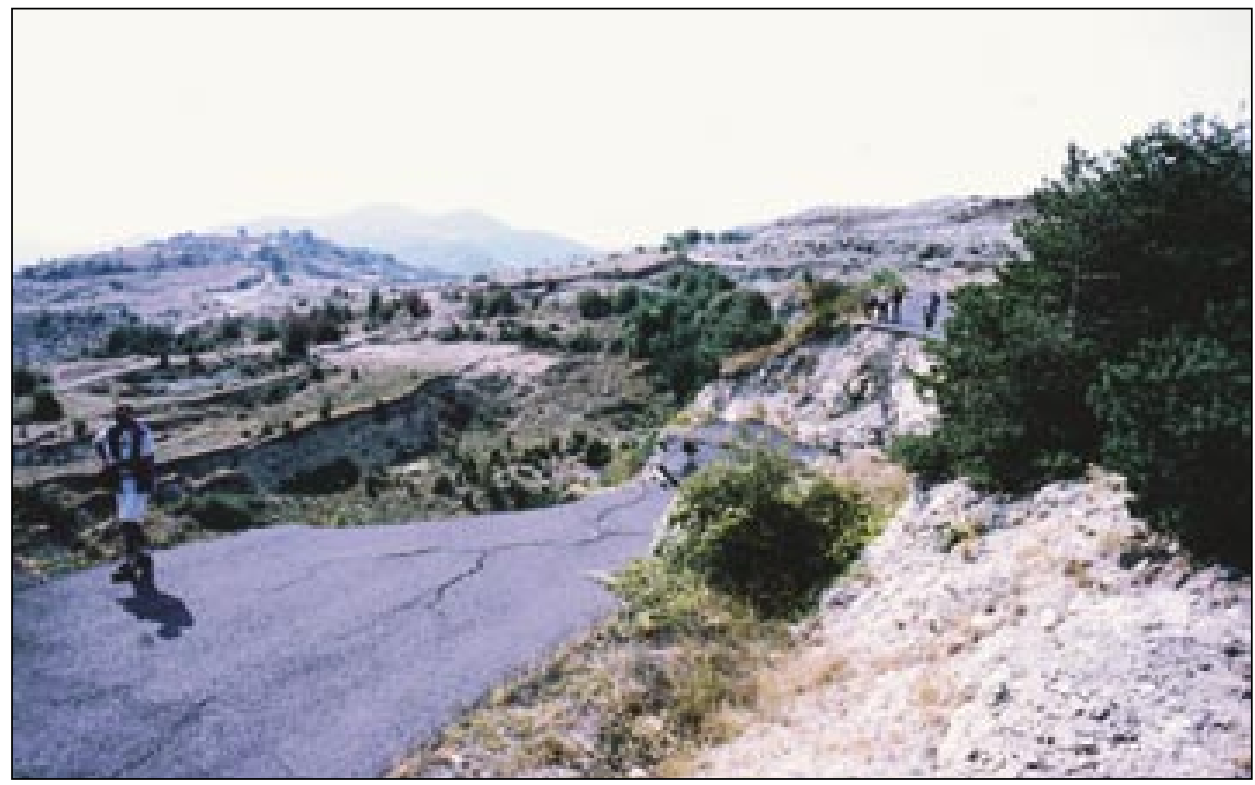

Figure 2: Active landslide in SE Bulgaria (photo S. Šebela).

Slika 2: Aktivni plaz v JV Bolgariji (foto S. Šebela). 


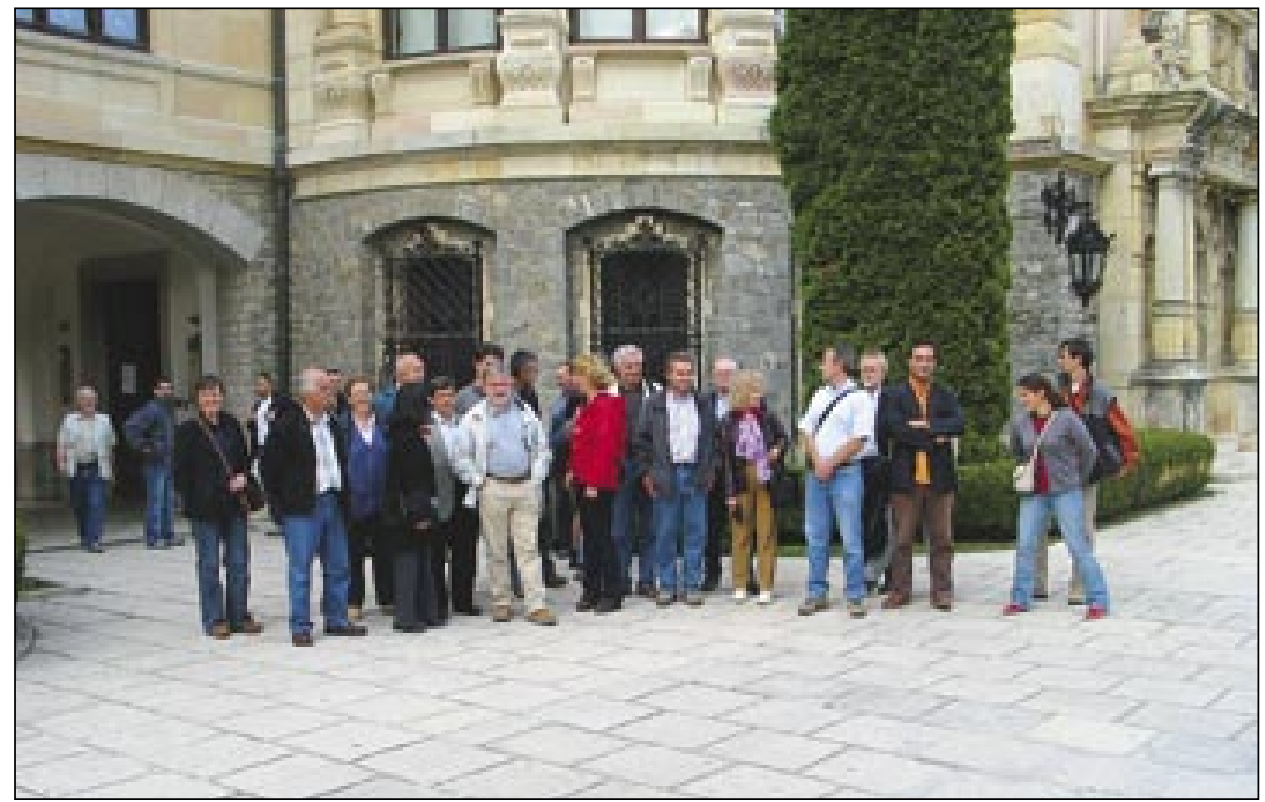

Figure 3: COST 625 participants in Romania, Sinaia (photo J. Mulec). Slika 3: Udeleženci srečanja COST 625 v Romuniji, Sinaia (foto J. Mulec).

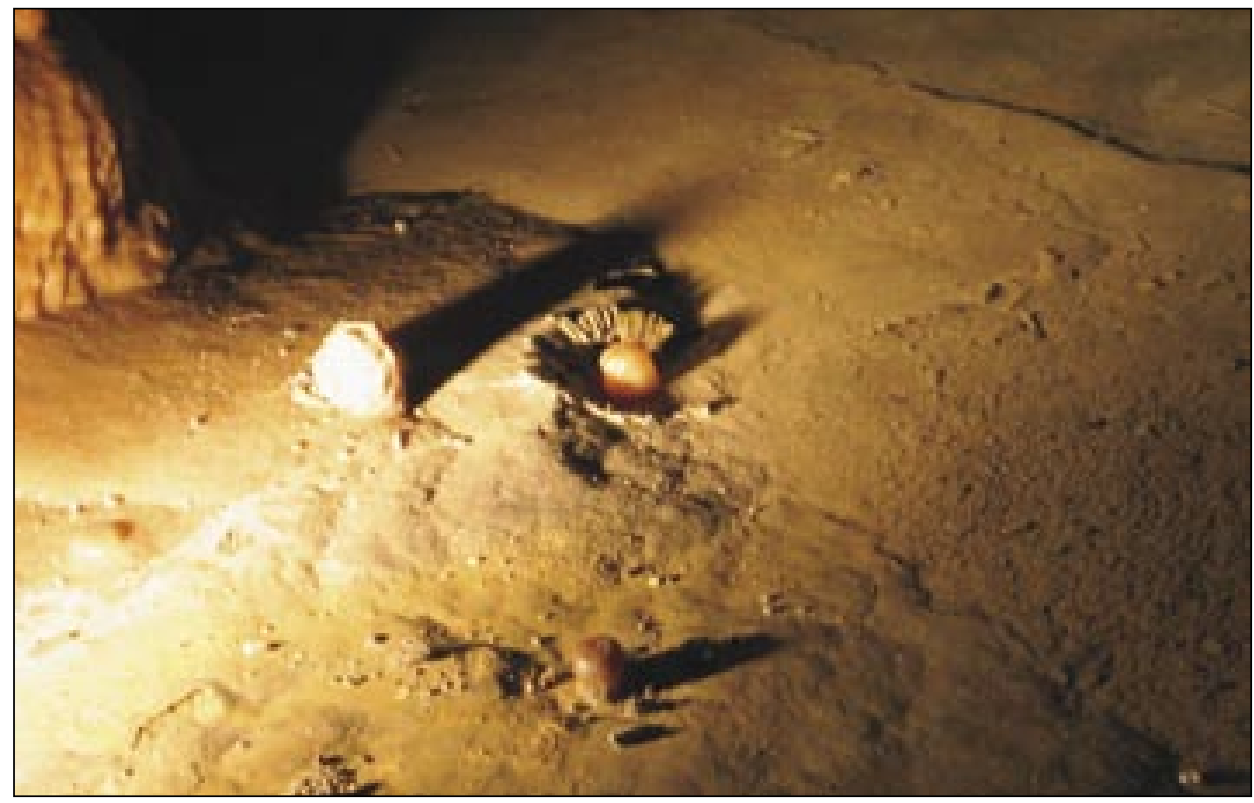

Figure 4: Demänova cave of Liberty (photo J. Mulec). Slika 4: Demänovska jama (foto J. Mulec). 
to the east of the town of Plovdiv, between villages of Popovitsa and Milevo, near the towns of Chirpan and Galabovo. The Parvomai oblique (dextral-normal) fault zone is characterized by 1928 and post-1928 vertical offsets of up to $3 \mathrm{~m}$. The recent rate of vertical movement is $3 \mathrm{~mm} / \mathrm{yr}$ and the rate of lateral one is $4.5 \mathrm{~mm} / \mathrm{yr}$ (Matova et al., 1996).

At the Romania meeting (Figure 3) fieldwork lead us to South-Eastern Carpathians and Cheia National Seismic Observatory. Vrancea area is a very active seismic zone in Romania. Just one day after the COST 625 meeting (September 27, 2004) in Vrancea area there was an earthquake with $\mathrm{M}=4.8$.

In 2005 we visited Demanova Cave of Liberty (Figure 4) in Slovakia. In the cave from August 2001 the TM 71 instrument is installed. The cave was mainly formed in the Middle Triassic limestones. The underground spaces are concentrated along the NNW-SSE oriented faults. The faults are quasi-parallel with an active fault in the Demanova valley (Hók et al. 2000) and are supposed to be responsible for several $\mathrm{mm}$ wide freshly opened cracks in several stalagmites. Conditions inside the cave are suitable for precise measurements because of small variations in temperature (from 6- $7^{\circ} \mathrm{C}$ ) and relative humidity (from 95-99\%). An interpretation of actual measurements revealed only a very small displacements along the $\mathrm{x}, \mathrm{y}$ and $\mathrm{z}$ axis $(0.1 \mathrm{~mm}$ per 31 months). Recorded micro-displacements probably reflect the small temperature changes inside rock massif along the fault planes (Petro et al. 2005).

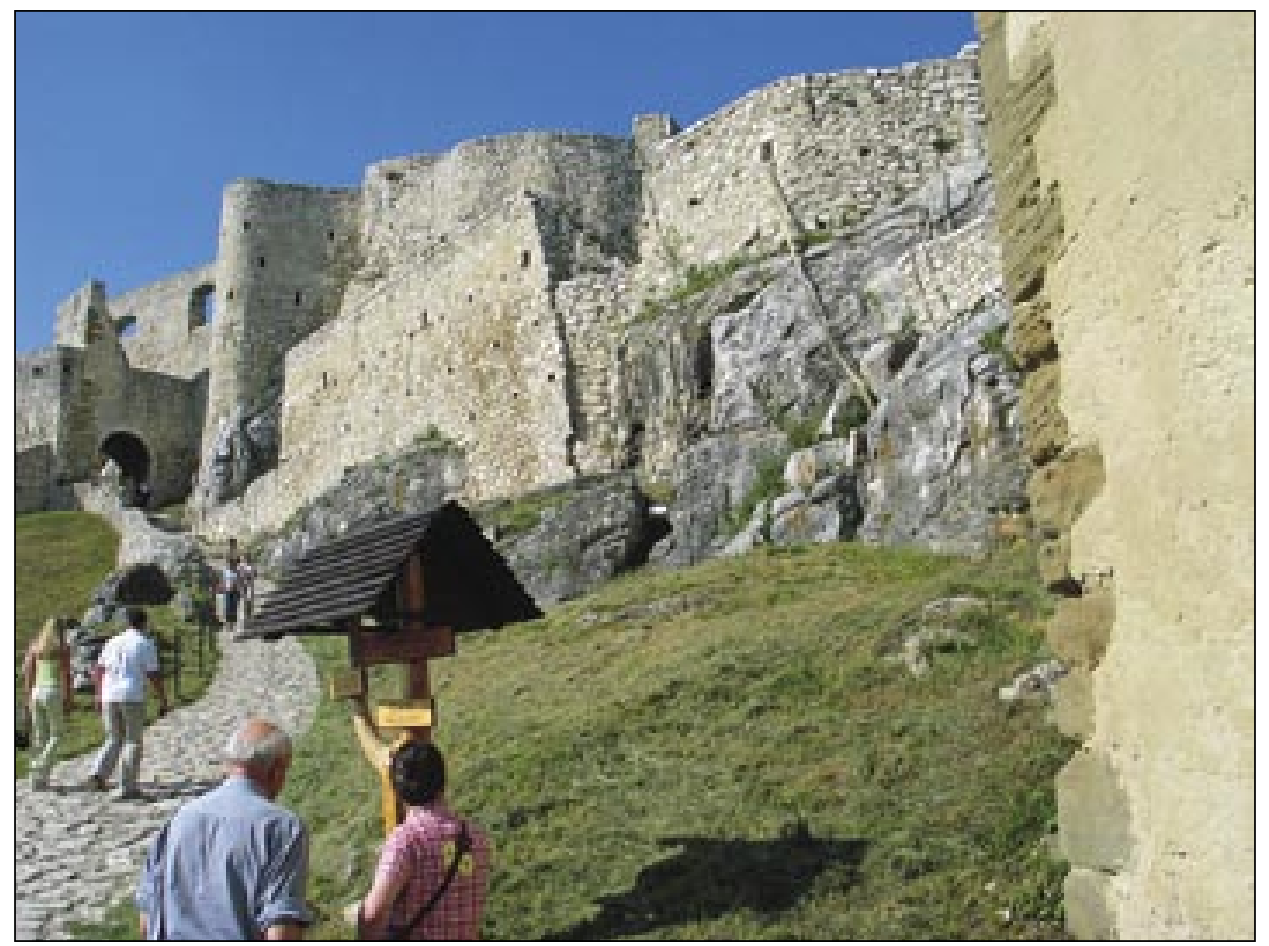

Figure 5: Spiš castle (photo J. Mulec).

Slika 5: Spiški grad 71 (foto J. Mulec). 
Very interesting was the visit of Špis castle (Figure 5). The castle represents the largest medieval fortification system in Central Europe. It was founded in 1120 and since 1993 is under the Patrimony of UNESCO. The castle is built on a travertine mound, which is underlain by Paleogene soft rocks formed by claystone and sandstone strata (flysch-like formation). The travertine reflects several features of destruction and is disturbed by a series of faults, cracks and joint systems. Long-term measurements proved that within the period of 1980-1994 the total extension of the crack recorded by TM 71 reached $14 \mathrm{~mm}$ (Vlčko \& Petro 2005).

Within the COST 625 project two Slovene students decided to work on the project related subjects. Vanja Kastelic works on the doctorate study of the Ravne fault and Mojca Kavčič on the TM 71 measurements in Slovenia. For both the mentor is dr. Andrej Gosar (University in Ljubljana).

In Slovenia we hosted also the participants of COST 625 from other countries (Table 3).

Slovenia was active in two Short-term scientific missions COST 625. The representatives of

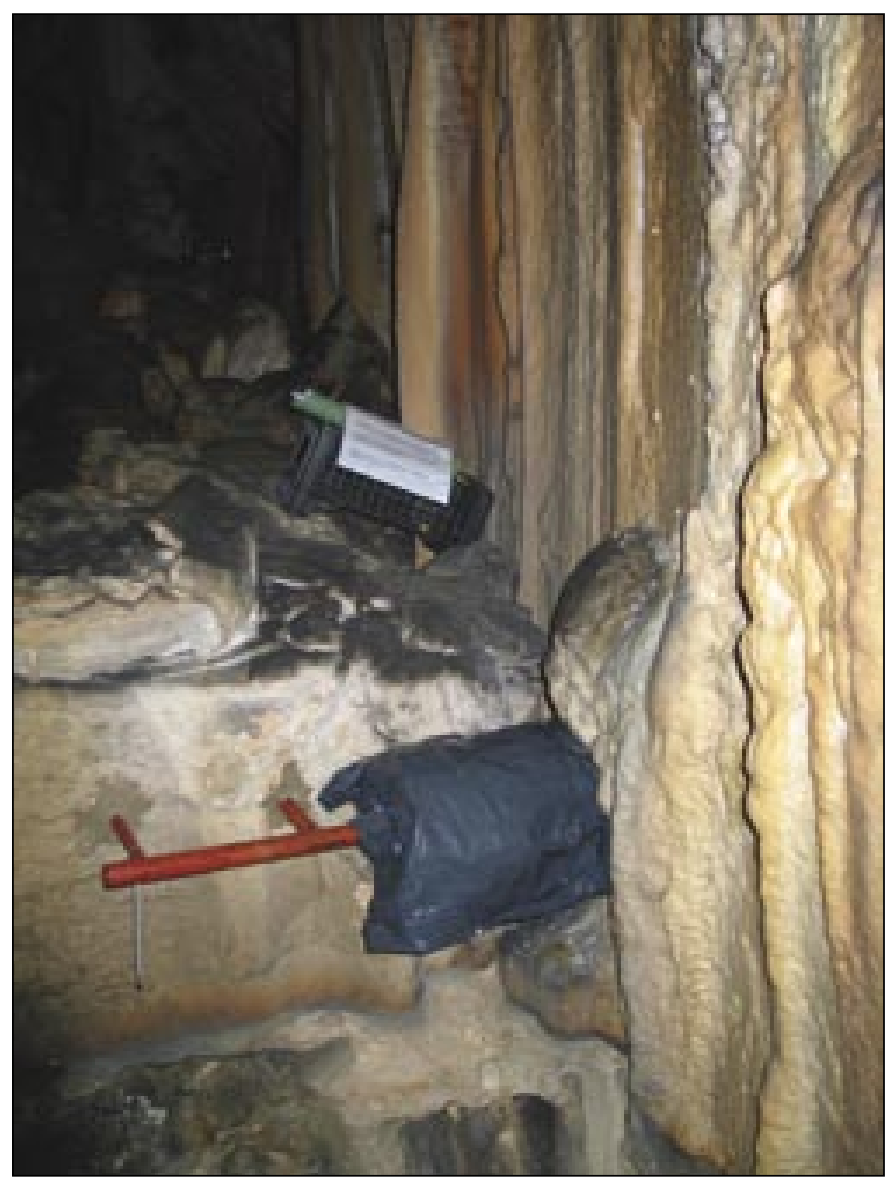

Institute of rock structure and mechanics, Academy of Sciences of the Czech Republic, dr. J. Stemberk and T. Nydl and two representatives from Geological Survey of Slovak Republic dr. L. Petro and dr. J. Hok visited Slovenia in November 2004 (Table 3). They finished the installation of TM 71 on Ravne and Idrija faults. On Kneža fault the installation still needs to be accomplished.

Dr. Janez Mulec gained his Short-term scientific mission (STSM) of COST 625 from February 7-11, 2005 in Gent, Belgium. Under the patronage of Babbage Institute for Knowledge and Information Technology (BIKIT) he worked on the project "Application of the 3D visualization in the case study of tectonically active region near Postojnska

Figure 6: TM 71 and barasol installation in Velika Gora. (photo J. Jama cave for a generally Mulec).

Slika 6: TM 71 in barasol na Veliki gori (foto J. Mulec). purpose use". The result 


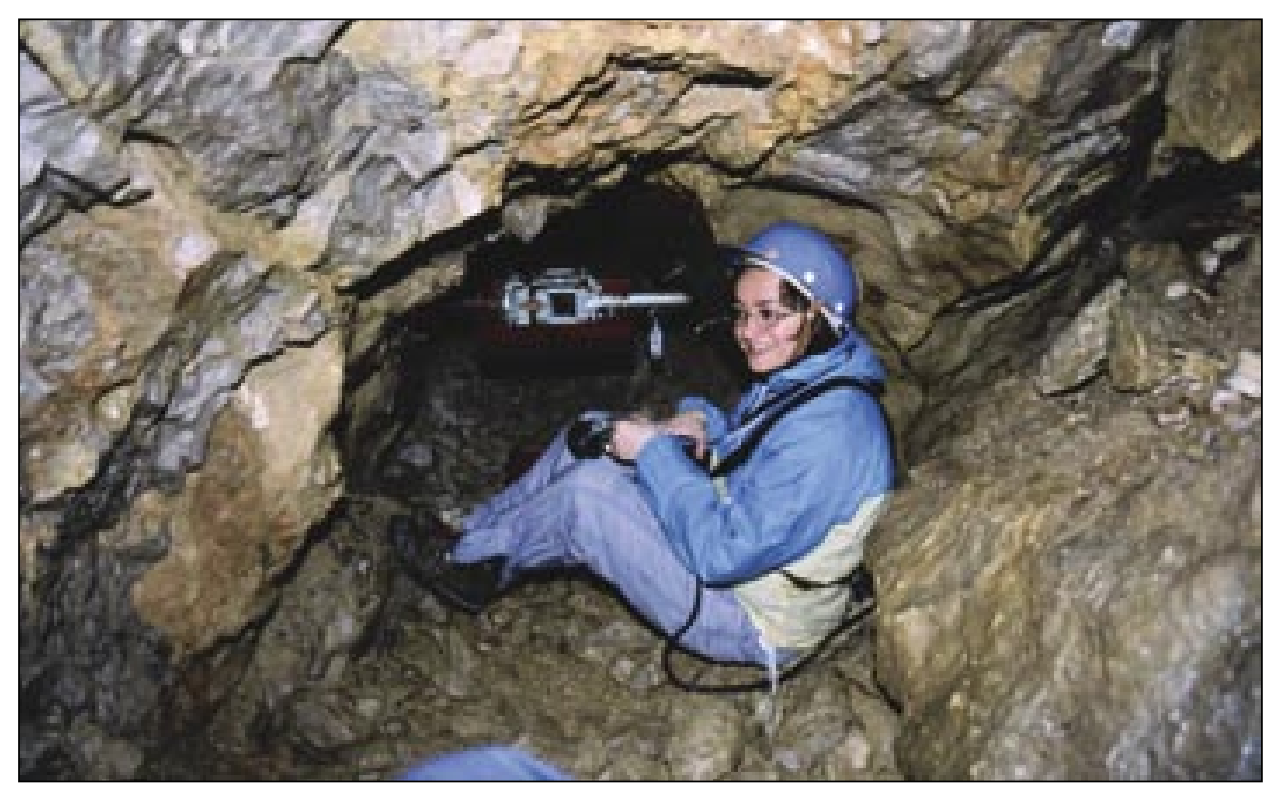

Figure 7: Artificial tunnel in Postojnska Jama and TM 71 (photo S. Šebela). Slika 7: Umetni tunel v Postojnski jami in TM 71 (foto S. Šebela).

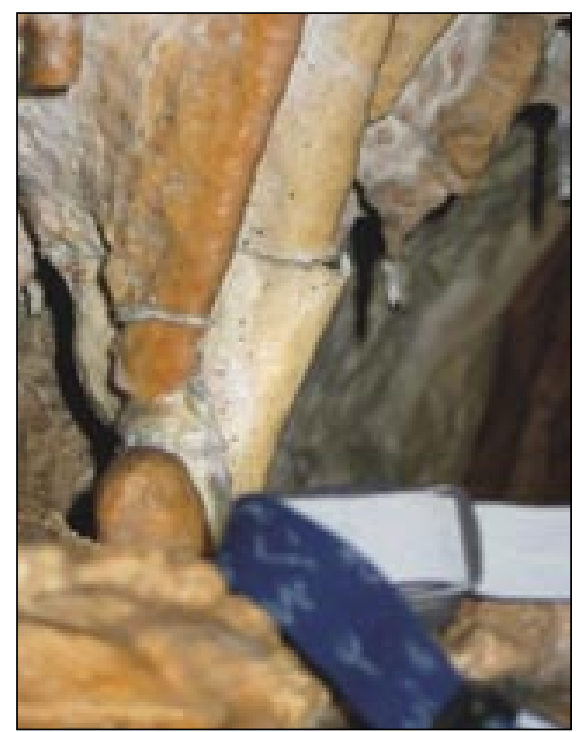

Figure 8: Deformed flowstone in Velika Gora (photo S. Šebela).

Slika 8: Deformiran kapnik na Veliki gori (foto S. Šebela). of the STSM is a 61 seconds $824 \mathrm{~KB}$ interactive movie on the Pivka valley made by Macromedia Flash MX 2004.

\section{TECTONIC ACTIVITY IN SLOVENIA AND TM 71 MONITORING IN POSTOJNSKA JAMA}

Most of Slovenia belongs to the most Northern part of the African plate to the Adria plate respectively (Anderson \& Jackson, 1987). The studies are suggesting the deformations on the $\mathrm{E}, \mathrm{W}$ and $\mathrm{N}$ edge of the Adriatic microplate, what is the result of its counter clockwise rotation (Weber et al., 2004). The principal aseismic outcrop of Adria microplate is Istra. The GPS measurements in Slovenia are suggesting the sharp (some mm/year) dextral (transpressive) movements along the Sava fault and Periadriatic fault line, what shows that the side intrusion in NE Alps is still active (Weber et al., 2004).

Most of the earthquakes that occurred in Slovenia in the last years were situated along Raša and 
Idrija faults (Michelini et al., 1998) and also along Ravne fault. Earthquakes are mostly showing the dextral activities along the active faults (Poljak et al., 2000).

TM 71 is used in Greece, Poland, Italy, Germany, Bulgaria, Slovakia, Czech Republic, Peru, Slovenia and Asia. Due to the stable temperature conditions in caves they are very suitable for TM 71 installations. Such cases are in Czech Republic, Poland, Slovakia and Slovenia. In Germany (Štemberk et al., 2003) and in Slovakia the instruments are placed in artificial tunnel. On the Gargano peninsula TM 71 is situated in the basement between the wall and Mattinata fault plane (Borre et al. 2003).

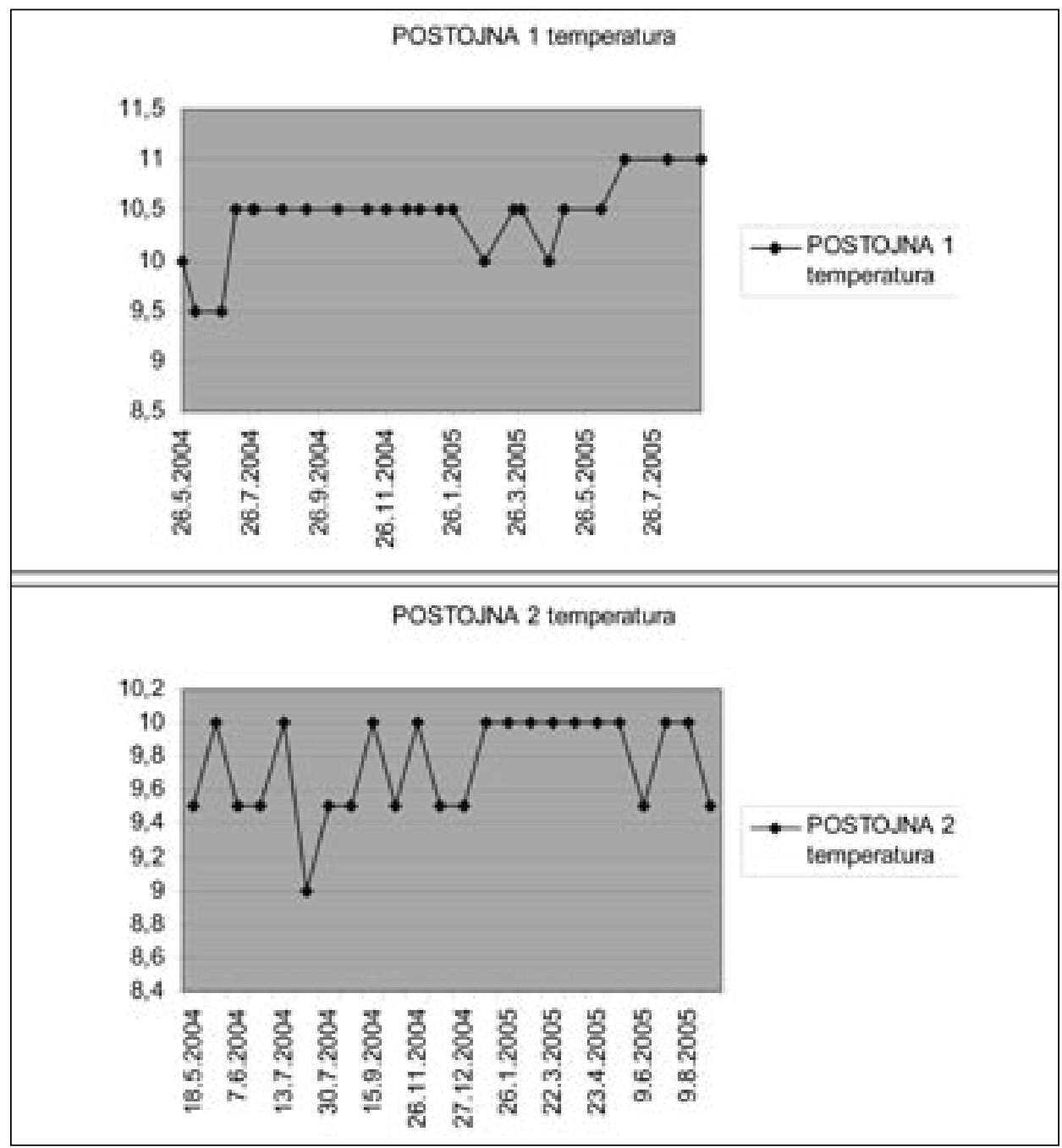

Figure 9: Temperature $\left({ }^{\circ} \mathrm{C}\right)$ in monitoring sites Postojna 1 and 2. Slika 9: Temperatura $\left({ }^{\circ} \mathrm{C}\right)$ na opazovanih mestih Postojna 1 in 2. 
In Slovenia TM 71 was first installed in February 26, 2004 in Postojnska Jama (Postojna 2, Lepe jame) and in May 26, 2004 on Velika Gora (Postojna 1).

Postojnska Jama (Gospodarič, 1965; Šebela, 1998) is situated between two important regional faults, Idrija fault on the North and Predjama fault on the South. The area between two dextral strikeslip faults includes the thrusting and folding deformations from Miocene and Pliocene and younger faulting. The cave passages are developed inside both anticline flanks and are following the bedding plane direction, the dip of the bedding planes and Dinaric and cross Dinaric fault zones.

The Northern edge of Velika Gora collapse chamber is developed along Dinaric oriented fault with visible vertical movement for some meters (Postojna 1). The same fault zone can be traced in other parts of the cave but with different kinematics as on Velika Gora. On the same fault zone in Lepe Jame (Postojna 2) vertical and horizontal movements can be detected. In Lepe Jame the same Dinaric fault is cut by younger cross Dinaric fault that was active less than 780.000 years ago (Sasowsky et al., 2003).

The instrument in the monitoring point Postojna 1 is situated between fault plane of the Dinaric fault and collapse block $(0,5 \times 1 \mathrm{~m})$ (Figure 6). The second monitoring point Postojna 2 is situated inside $1 \times 1 \mathrm{~m}$ wide artificial tunnel where TM 71 is installed between two Dinaric fault planes (Figure 7). The Dinaric fault that is studied by TM 71 is situated about $1 \mathrm{~km}$ North from the Predjama fault zone.

Along the Dinaric fault zone in Velika Gora we can even find some broken flowstone (Figure 8) that might be the result of tectonic deformations along the fault.

The instruments are monitored once a month, and in the case of stronger earthquakes even more frequent. The cave has stable temperature, in Velika Gora $9,5-11^{\circ} \mathrm{C}$ and in Lepe Jame $9-10^{\circ} \mathrm{C}$ (Figure 9).

\section{CONCLUSIONS}

TM 71 instruments in Slovenia are not installed just in karst cave, but also on the surface. From November 2004 Idrija fault in Učja valley and Raša fault in the SE slope of Vremščica are being monitored (Šebela \& Gosar 2005). The location on Kneža fault (South from Ravne fault) still needs the final installation.

In May 2004 Idrija fault was surveyed and in May 2005 the Ravne fault was surveyed for LiDAR mapping of seismogenic faults in NW Slovenia. Aerial measurements with high-resolution Laser device giving precise image of the topography were supported with GPS ground measurements on selected base stations. The action is a result of a successful application of Dickson Cunningham (University of Leicester) and Andrej Gosar (University of Ljubljana) to British Natural Environment Research Council (NERC). The results are still in progress.

On the initiative of Mladen Živčić (ARSO, Ljubljana) two barasol instruments were installed by dr. Ivan Kobal and dr. Boris Zmazek (Inštitut Jožef Stefan, Ljubljana) on the July 1, 2005 close to the TM 71 monitoring points in Postojnska Jama (Figure 6). The instruments are measuring the radon concentrations, temperature and air pressure every hour. We would like to find the connection between tectonic activity and radon concentrations.

First results of the TM 71 monitoring in Postojnska Jama are suggesting small horizontal movements of $0.05 \mathrm{~mm}$ in one year. 
Just before or during the earthquake of July 12, 2004 in NW Slovenia (M=4.9) both devices recorded the same reaction. Before the earthquake the displacement along y axis corresponded to right lateral movement and just before or during the earthquake the movement changed to left lateral with a step about $0.03 \mathrm{~mm}$ (Šebela et al. 2005).

The representative results could be obtained after three or more years of monitoring. It will be interesting to compare the results from the cave (outer fault zone of Predjama fault) and from the surface (inner fault zone of Raša and Idrija faults).

Mocchiutti \& D'Andrea (2002) studied the recent tectonic movements in NE Italy. They say that the caves are the only place where it is possible to recognize with precision the most recent movements at the millimeter scale. In the area of Udine (NE Italy) some mechanical measuring instruments (extensometers, fissuremeters and pendulum) have been positioned. The monitoring of one of these extensometers in karst cave has shown a movement of 0,12 mm from 1999 to 2002 (Mocchiutti \& D'Andrea (2002), what represents the similar movement as in Postojnska Jama.

In Postojnska Jama the measurements with TM 71 will go on for years. We would like to find more proves for the relation between movements registered by TM 71 and active tectonics. We need to consider also the water percolation from the surface into the cave and possible TM 71 response, the stability of the cave underground and the possible relation between radon and tectonic activity. One of the important facts will be the comparison of results between TM 71 installations in different caves all over the Europe with statistical evaluation.

\section{REFERENCES}

Anderson, H. \& Jackson, J., 1987: Active tectonics of the Adriatic region.- Geophys. J. R. Astron. Soc., 91, 937-983.

Avramova-Tacheva, E. \& Koštak, B., 1986: Direct measurement of recent movements along seismic faults and creep deformations.- Proc. 5th Int. Congr. IAEG, Buenos Aires, 337-346.

Avramova-Tacheva, E. \& Koštak, B., 1995: Local three-dimensional extensiometric measurements for the determination of displacements in the Krupnik fault zone, Bulgaria.- Acta montana IRSM AS CR, series A, no. 8 (97), 87-98.

Borre, K., Cacon, S., Cello, G., Kontny, B., Košt’ák, B., Likke Andersen, H., Moratti, G., Piccardi, L., Stemberk, J., Tondi, E. \& Vilimek, V., 2003: The COST project in Italy: analysis and monitoring of seismogenic faults in the Gargano and Norcia areas (central-southern Apennines, Italy).- Journal of Geodynamics 36, 3-18.

Brouchev, I., Frangov, G. \& Yanev, Y., 2001: Landslides in the Dzhebel region (Eastern Rhodope Mountains).- Geologica Balcanica, 31, 1-2, 96-98, Sofia.

Gospodarič, R., 1965: Tektonika ozemlja med Pivško kotlino in Planinskim poljem ter njen pomen za sistem Postojnskih jam.- 179 str. in 38 prilog, Postojna (elaborat. IZRK ZRC SAZU, Postojna).

Hók, J., Bielik, M., Kovač, P. \& Šujan, M., 2000: Neotektonický character územia Slovenska.Mineralia Slovaca 32 (5), 459-470.

http://fir.seismology.hu/cost625/

Kalvoda, J. \& Košt’ák, B., 1984: Geomorfologicka analyza mereni piskovcovych bloku v udolini Libechoky.- Sbor. Čs. Geogr. Společ. 89, 3, 199-21. 
Košt’ák, B., 1969: A new device for in-situ movement detection and measurement.- Exp. Mechanics 9, Easton (Pa, USA), 374-379.

Košt’ák, B., 1977: Terčové měřidlo TM-71 a jeho užití pro měření velmi pomalých pohybů na poruchách a trhlinách.- Inž. Stavby 25, 5, 213-218.

Košt’ák, B., 1991: Combined indicator using Moiré technique. - Proc. 3rd Int. Symp. on Field Measurements in Geomechanics, 9-11 Sept. 1991 Oslo, 1, 53-60, Balkema, Rotterdam, Brookfield.

Košt'ák, B. \& Avramova-Tacheva, E., 1984: Propagation of coastal slope deformations at Taukliman, Bulgaria.- Bull IAEG 23, 67-73.

Matova, M., Spiridonov, H., Rangelov, B. \& Petrov, P., 1996: Major Active Faults in Bulgaria.Journal of Earthquake Prediction Research 5, 436-439.

Michelini, A., Živčić, M., Suhadolc, P., 1998: Simultaneous inversion for velocity structure and hypocenters in Slovenia.- Journal of Seismology, 2, 257-265.

Mocchiutti, A. \& D'Andrea, A., 2002: Morphologic evidence of recent and modern tectonic movements in some caves of the Friuli Prealps (northeastern Italy).- Mem. Soc. Geol. It., 57, 487-491.

Petro, L., Polaščinova, E., Stercz, M. \& Košt'ak, B., 2005: Current results from 3-D monitoring of active faults in the Western Carpathians.- Acta Geodyn. Geomater., vol. 2, no. 1, 37-43, Prague.

Poljak, M., Živčić, M., Zupančič, P., 2000: The seismotectonic charateristics of Slovenia.- Pure and Applied Geophysics. 157, 37-55.

Sasowsky, I.D., Šebela, S. \& Harbert, W., 2003: Concurrent tectonism and aquifer evolution > 100,000 years recorded in cave sediments, Dinaric karst, Slovenia.- Environmental Geo$\operatorname{logy} 44: 8-13$.

Shanov, S., 1993: Medium-time earthquake prediction based on tectonic fault zone displacement data.- Acta montana A4 (90), 53-62.

Stemberk, J., Košt’ák, B. \& Vilimek, V., 2003: 3D monitoring of active tectonic structures.- Journal of Geodynamics 36, 1-2, 103-112.

Šebela, S., 1998: Tectonic structure of Postojnska Jama cave system.- Založba ZRC 18, 112 pp., Ljubljana.

Šebela, S. \& Gosar, A., 2005: Začetek meritev premikov ob prelomih v zahodni Sloveniji s 3D ekstenziometri TM 71.- Raziskave s področja geodezije in geofizike. 10. strokovno srečanje Slovenskega združenja za geodezijo in geofiziko, Ljubljana, 13. januar 2005, 37-45, Ljubljana.

Šebela, S., Gosar, A., Košták, B. \& Stemberk, J., 2005: Active tectonic structures in the W part of Slovenia - Setting of micro-deformation monitoring net.- Acta Geodyn. Geomater., Vol. 2, No. 1 (137), 45-57, Prague.

Vlčko, J. \& Petro, L., 2005: Spiš Castle.- Field trip guidebook, COST Action 625, Bratislava/Demanova, Slovak Republic, May 26-28, 2005, 5-9, Bratislava.

Zupančič, P., Cecić, I., Gosar, A., Placer, L., Poljak, M., Živčić, M., 2001: The earthquake of 12 April 1998 in the Krn Mountains (Upper Soča valley, Slovenia) and its seismogenic characteristics.- Geologija 44/1, 169-192.

Weber, J.C., Vrabec, M., Stopar, B. \& Dixon, T., 2004: New GPS constrains on Adria microplate kinematics, dynamics, and rigidity from the Istria peninsula, Slovenia and Croatia.-GSA Abstracts with Programs, Vol. 36, No. 5. 


\section{SPREMLJANJE AKTIVNIH TEKTONSKIH STRUKTUR - PROJEKT COST 625}

\section{Povzetek}

Za zahodno Slovenijo je značilna zmerna zgodovinska in recentna seizmičnost. Potresi v Posočju $\mathrm{v}$ zadnjih desetih letih nas opozarjajo na aktivne prelomne cone, predvsem na Ravenski in Kneški prelom. Za nekatere druge morfološko dobro izražene prelome pa je prav zaradi pomanjkanja seizmične aktivnosti ob njih težko govoriti, ali so tektonsko aktivni ali ne. Glavni cilj pridružitve Slovenije k projektu COST 625 je bil, da bi z izmenjavo izkušenj in metodologije z drugimi državami udeleženkami ugotovili aktivnost ali neaktivnost določenih prelomov v zahodni Sloveniji.

V okviru projekta se kot glavne metode raziskav uporabljajo:

- geološko in geomorfološko kartiranje terena, pri čemer se kartirajo površinski pretrgi ob prelomih, kot tudi drugi morfološki znaki (npr. zamaknjene rečne doline, premaknjene rečne terase itd.)

- seizmične analize

- GPS, LiDAR in geodetske meritve

- merjenje premikov z ekstenziometri, predvsem s TM 71.

V Sloveniji smo se za ustrezno novo metodo odločili za ekstenziometer TM 71, ki ga je razvila skupina na Inštitutu za strukture kamnin in mehaniko Češke akademije znanosti pod vodstvom dr. Blahoslava Košt’áka in ga tudi patentirala (Košt'ák, 1969). Gre za mehansko-optični inštrument, ki meri premike $\mathrm{v}$ treh oseh $(x, y$ in $z) \mathrm{z}$ natančnostjo $0,01 \mathrm{~mm}$ (Šebela et al. 2005).

K projektu COST 625 (“3-D monitoring of active tectonic structures”) je Slovenija, s podpisom memoranduma o sodelovanju, pristopila 16. marca 2000. Danes je v projekt vključenih 21 držav. Sprva je bil projekt del domene okolje, od avgusta 2004 pa je del kulturne dediščine. Uradni začetek projekta je 9.2.2000 in konec 8.2.2006. Projekt poteka v dveh delovnih skupinah (WGAT - Delovna skupina za aktivno tektoniko; WGMI - Delovna skupina za monitoring in opremo). Glavni cilj je raziskovanje mikro premikov na aktivnih tektonskih strukturah, ki so lahko seizmični ali aseizmični.

Sodelujoče države pri projektu COST 625 so v šestih letih opravile 11 srečanj članov odbora. Aktivnost skupine sta vseskozi podpirala prvi predsednik COST 625 dr. Blahoslav Košták in sedanji predsednik dr. Luigi Piccardi. V Tabeli 1 je seznam srečanj (http://fir.seismology.hu/cost625/) in terenskega dela, v tabeli 2 pa slovenski udeleženci na COST 625 srečanjih. V Sloveniji smo gostili tudi sodelavce COST 625 iz drugih držav (Tabela 3). Slovenija je sodelovala pri dveh Short term scientific missions COST 625. Predstavniki Institute of rock structure and mechanics, Academy of Sciences of the Czech Republic, dr. J. Stemberk in T. Nydl ter predstavnika Geological Survey of Slovak Republic dr. L. Petro in J. Hok so v Novembru 2004 (Tabela 3) opravili dokončne namestitve TM 71 inštrumentov v Sloveniji, in sicer na Raškem in Idrijskem prelomu ter pripravili vzorčno mesto na Kneškem prelomu, ki pa še čaka na dokončno namestitev inštrumenta TM 71.

Dr. Janez Mulec se je v okviru Short term scientific mission (STSM) COST 625 udeležil izpopolnjevanja v Gentu v Belgiji (7-11 February 2005).

V Sloveniji smo TM 71 prvič namestili 26.februarja 2004 v Postojnski jami (Postojna 2, Lepe jame) in 26.maja 2004 na Veliki gori (Postojna 1).

Postojnska Jama (Gospodarič, 1965; Šebela, 1998) leži med dvema pomembnima dinarsko usmerjenima prelomoma, Idrijskim na severu in Predjamskim na jugu. Ozemlje je razkosano z deformacijami narivanja in gubanja miocenske in pliocenske starosti ter mlajšega prelamljanja. Jamski rovi so razviti v obeh krilih Postojnske antiklinale in sledijo slemenitvi plasti in smeri vpada plasti 
ter dinarskim in prečnodinarskim prelomnim conam.

Severni rob podorne dvorane Velika gora je razvit znotraj dinarske prelomne cone z vertikalnim premikom za nekaj metrov (Postojna 1). Prav to prelomno cono lahko zasledimo tudi v drugih delih jame, vendar tam ne kaže enakih smeri premikov. V Lepih jamah znotraj iste prelomne cone zasledimo dokaze za vertikalne in horizontalne premike (Postojna 2). V Lepih jamah je ta dinarska prelomna cona tudi prekinjena z mlajšo prečnodinarsko prelomno cono, ki je bila aktivna v obdobju mlajšem od 780.000 let (Sasowsky et al., 2003).

Na Veliki gori je TM 71 (Postojna 1) postavljen med prelomno ploskvijo strmega dinarskega preloma in zasiganim podornim blokom apnenca velikosti 0,5 x $1 \mathrm{~m}$ (Slika 7). Drugo opazovano mesto (Postojna 2) predstavlja krajši umetno izkopan rov velikosti 1 x 1 m, kjer je TM 71 postavljen med dve dinarski prelomni ploskvi (Slika 8). Opazovani dinarski prelom leži približno 1 km severno od Predjamskega preloma. Odčitke premikov opravljamo enkrat na mesec, po večjih potresih pa opravimo še dodatne meritve. $\mathrm{V}$ jami je stalna temperatura, na Veliki gori med $9,5-11^{\circ} \mathrm{C}$ in v Lepih jamah med $9-10^{\circ} \mathrm{C}$ (Slika 9).

TM 71 inštrumenti so v Sloveniji postavljeni tudi na površju. Od novembra 2004 opazujemo Idrijski prelom v dolini Učje in Raški prelom na JV pobočju Vremščice. Lokacija na Kneškem prelomu (južno od Ravenskega) pa še čaka na dokončno instalacijo. Gre za eno redkih aktivnih struktur v Sloveniji, kjer je seizmičnost povezana z znanim prelomom.

Pod vodstvom dr. Dicksona Cunninghama (University of Leicester) in dr. Andreja Gosarja (Univerza v Ljubljani) je bilo v maju 2004 opravljeno LiDAR kartiranje Idrijskega preloma in v maju 2005 Raškega preloma. Rezultati še niso na voljo.

Na pobudo Mladena Živčića (ARSO, Ljubljana) smo s pomočjo dr. Ivana Kobala in dr. Borisa Zmazka (Inštitut Jožef Stefan, Ljubljana) 1.julija 2005 v neposredni bližini obeh vzorčnih mest v Postojnski jami namestili 2 barasola za merjenje urnih koncentracij radona, temperature in zračnega tlaka (Slika 6). Opazovanje temelji na predpostavki, da se ob tektonskih aktivnostih poveča tudi koncentracija radona. Menimo, da bi v enem letu vzporednih meritev radona in premikov s TM 71 lahko dobili reprezentativne rezultate.

Prvi rezultati meritev s TM 71 v Postojnski jami (Postojna 1) kažejo na manjše horizontalne premike velikosti do $0.05 \mathrm{~mm}$ v enem letu.

V obdobju pred potresom v zahodni Sloveniji dne 12.7.2004 smo na obeh inštrumentih zaznali premik vzdolž y osi, levi zmik. Tik pred potresom ali med potresom pa se je premik $(0,03 \mathrm{~mm})$ obrnil v desni zmik (Šebela et al. 2005).

Reprezentativne rezultate bomo dobili šele $\mathrm{v}$ treh in več letih merjenja premikov s TM 71. Zanimiva bo tudi primerjava med rezultati iz Postojnske jame, kjer sta TM 71 inštrumenta nameščena na prelom v širši prelomni coni Predjamskega preloma in rezultati merjenja v notranji prelomni coni Idrijskega in Raškega preloma.

Mocchiutti \& D’Andrea (2002) sta v SV Italiji v obdobju 1999-2002 v kraški jami z ekstenziometrom določila premik 0,12 mm. Rezultat je primerljiv z meritvami v Postojnski jami.

Merjenja premikov s TM 71 v Postojnski jami se bodo nadaljevala več let. Želimo si pridobiti več dokazov o odvisnosti registriranih premikov in tektonski aktivnosti. Upoštevati pa moramo tudi druge možnosti, kot vpliv pretakanja vode v krasu, nestabilnost jamskih tal ter odnos med radonom in aktivno tektoniko. Pomembna bo tudi statistična primerjava rezultatov meritev s TM 71 iz različnih kraških jam po Evropi. 
